\title{
CUIDADO AO DOENTE: Uma visão fenomenológica
}

\author{
Care of the diseased person: A phenomenological view
}

Silva, L. C. de. (2009). O cuidado na vivência do doente de câncer: Uma compreensão fenomenológica. Maringá: Eduem.

\section{Regina Célia Veiga da Fonseca}

Psicóloga, Doutoranda do Programa de Pós-Graduação em Biotecnologia aplicada à Saúde da Criança e do Adolescente das Faculdades Pequeno Príncipe (FPP), professora dos Cursos de Enfermagem e Biomedicina das Faculdades Pequeno Príncipe, Curitiba, PR - Brasil, e-mail: fonsecaregina@hotmail.com

"O cuidado na vivência do doente de câncer: Uma compreensão fenomenológica (2009, p. 148), da psicóloga Lúcia Cecília da Silva, propõe uma reflexão humanista aos profissionais da saúde que prestam cuidados ao ser humano que sofre, a partir do diagnóstico e o tratamento de um câncer. Um ser humano que sofre, não apenas com a doença em si, mas também com as dimensões existenciais da sua vida e a possibilidade de não-mais-ser-aí-no-mundo.

A obra, resultado de uma pesquisa da autora, apresenta de forma clara e didática o sentido do cuidado sob a ótica do paciente. Apresenta e discute o ser-aí-no-mundo desses pacientes sob a luz da fenomenologia heideggeriana.

Para atingir tal objetivo, os primeiros capítulos do livro discorrem sobre o câncer em seus aspectos psicossociais, os impactos da doença no existir de um ser, fazendo-o vivenciar o que a autora chama de desalojamento do ser do mundo. Depois, fala sobre o funcionamento do atendimento ao paciente oncológico no país: o cuidado como preocupação da Saúde Pública.

O capítulo 3 analisa o cuidado, além do que geralmente se concebe sobre esse conceito nas práticas de saúde. Para tanto, retoma o sentido do cuidado desde os primórdios até chegar às noções oferecidas por Heidegger. Finaliza afirmando que sem cuidado não há verdadeiramente homem.

O capítulo 4 descreve a experiência do doente com câncer. Os discursos dos pacientes oncológicos entrevistados são descritos e analisados. O fenômeno é apresentado na subjetividade de cada ser-com-câncer, constituindo-se em rica fonte de reflexão para o leitor.

Em seguida, o capítulo 5 aborda a existencialidade do doente com câncer. Discute a experiência da "falta" na vida do ser humano, a partir do surgimento do câncer. Debate a doença como um ente capaz 
de provocar uma ruptura das certezas da vida, mostrando claramente a possibilidade do não-mais-seraí-no-mundo e a angústia desencadeada por tal ameaça. O capítulo aborda o desafio, imposto ao doente, de transcender à facticidade da doença e de responsabilizar-se pelo seu novo projeto existencial.

O último capítulo enriquece a concepção heideggeriana acerca do cuidado, acrescentando a concepção de doentes oncológicos que relatam suas preocupações em relação ao cuidado, à dedicação do doente consigo mesmo e à dedicação dos outros em relação a ele.

Este livro possibilita melhorias nas práticas do cuidado ao ser adoecido com câncer, visto que sugere reflexões valiosas para todos os profissionais da saúde e, com isso, permite uma nova perspectiva sobre a compreensão da existência humana. A autora espera que esse novo pensar possibilite um acolhimento mais sereno e humanizado ao ser que sofre em sua vivência com o câncer. 